Original

\title{
First line oral vinorelbine in elderly patients with advanced non-small-cell lung cancer
}

\author{
M. Cobo Dols, S. Gil Calle, E. Villar Chamorro, I. Alés Díaz, J. Alcalde García, V. Gutiérrez Calderón, \\ G. Durán Ogalla, J. Martínez Galán, F. Carabante Ocón, J. J. Bretón García, M. Benavides Orgaz
}

\section{Summary}

Purpouse: The activity of vinorelbine (VRL) as single agent in treatment-naïve inoperable non small cell cancer (NSCLC) patients (pts) has been assessed in several published studies. Oral and intravenous formulation have a linearity of VRL pharmacokinetics with both routes of administration. This is a study with oral VRL in first line advanced NSCLC in elderly pts.

Patients and methods: A total of 12 chemonaive elderly pts $\geq 70$ years were recruited from October 2005 through to June 2006. Principal inclusion criteria included histologically confirmed advanced NSCLC, performance status $\leq 2$, measurable disease, appropriate bone marrow and organ function. The dosage schedule was $60 \mathrm{mg} / \mathrm{m}^{2}$ once a week for three weeks (first cycle), followed if not toxicity by $80 \mathrm{mg} / \mathrm{m}^{2}$ once a week, until disease progression or development of unacceptable toxicity.

Results: The mean age was 74 years (range: 71 to 79), all males, and all pts stage IV. Histology subtypes: adenocarcinoma in 5 pts, large cell carcinoma in 1 pts and squamous cell carcinoma in 6 pts. PS (ECOG) distribution was: 3 pts with PS 1, and 9 pts with PS 2. The median weekly VRL doses was 13 (range 3-23). Out of 11 pts receiving the second cycle, 7 patients went a dose escalation to 80 $\mathrm{mg} / \mathrm{m}^{2}$. The other $4 \mathrm{pts}$ remained at the $60 \mathrm{mg} / \mathrm{m} 2$ dose level. There were no complete responses (CR). Two (13\%) of 12 patients achieved partial response (PR). There were $6(50 \%)$ stable disease (SD) and $4(34 \%)$ progressive disease (PD). Respect survival, the median follow-up was 4 months (range 1-9 months). Until date, the median survival time (MST) and median progression-free survival had not been reached; and survival and progression-free survival was $66 \%$ in both. Treatment with oral VRL in elderly patients was well tolerated, and there were no toxic deaths. No grade 4 toxicities were observed, and grade 3 toxicities were infrequent, exclusively neutropenia in 2 patients and asthenia in other 2 patients. Rest of toxicities were grade 1 or 2.

Conclusions: Oral VRL appears to be a reasonable alternative intravenous VRL, both in terms of activity and tolerability in advanced, elderly NSCLC patients

Key words: Chemotherapy. Oral vinorelbine. Elderly. Non small cell lung cancer .

Oncología, 2007; 30 (1):12-20

From the Medical Oncology Section of the Hospital Regional Universitario Carlos Haya

Málaga (Spain)
Recibido: 26.07 .06

Revisado: 10.08 .06

Aceptado: 04.09.06 


\section{Resumen}

Objetivo: La actividad de la vinorelbina (VRL) en monoterapia en primera línea en pacientes con cáncer de pulmón no microcítico (CPNM) ha sido contrastada en numerosos estudios. Las formulaciones tanto oral en intravenosa tienen un perfil farmacocinético paralelo. Presentamos un estudio con VRL oral en pacientes (pts) ancianos con CPNM avanzado en primera línea.

Material y métodos: Un global de 12 pts $\geq 70$ años fueron reclutados desde Octubre 2005 hasta Junio 2006. Los criterios de inclusión fueron: CPNM avanzado histológicamente confirmado, PS $\leq 2$, enfermedad medible, buena reserva medular y función orgánica adecuada. La dosis del esquema consistió en $60 \mathrm{mg} / \mathrm{m}^{2}$ semanal durante 3 semanas seguidas (primer ciclo), seguido de $80 \mathrm{mg} / \mathrm{m}^{2}$ semanal si no había toxicidad, hasta progresión o toxicidad inaceptable.

Resultados: La mediana de edad fue de 74 años (rango: 71-79), todos los pts fueron varones, e igualmente todos con estadio IV. Los subtipos histológicos se distribuyeron en: adenocarcinoma en 5 pts, carcinoma de células grandes en 1 pts y escamoso en 6 pts. Tres pts tenían PS 1 a la entrada en el estudio, y 9 pts PS 2, mientras que ninguno PS 0. La mediana de dosis de VRL administrada fue de 13 ciclos (rango 3-23). Contando los 11 pts que recibieron el segundo ciclo, 7 de ellos pudieron escalar a $80 \mathrm{mg} / \mathrm{m}^{2}$. Los otros 4 pts permanecieron en $60 \mathrm{mg} / \mathrm{m}^{2}$. No se observaron respuestas completas (RC), 2 pts alcanzaron una respuesta parcial (RP), 6 pts con enfermedad estable (EE) y 4 pts con enfermedad progresiva (EP). Respecto a la supervivencia, la mediana de seguimiento fue de 4 meses (rango 1-9 meses). Hasta la fecha, no se ha alcanzado la mediana de supervivencia ni la mediana de tiempo a la progresión. Tanto la supervivencia como la supervivencia libre de progresión (mediana de seguimiento 4 meses) fue del $66 \%$ respectivamente. Respecto a la toxicidad, la tolerancia fue buena y no hubo muertes tóxicas. No se observaron toxicidades grado 4, y las toxicidades grado 3 fueron infrecuentes, con sólo 2 pacientes con neutropenia grado 3 y otros dos pacientes con astenia grado 3 . Resto de las toxicidades fueron grado 1 ó 2.

Conclusiones: VRL oral puede ser una alternativa razonable a la administración intravenosa tanto en términos de actividad como de tolerabilidad en pacientes ancianos con CPNM avanzado.

Palabras clave: Quimioterapia. Vinorelbina oral. Ancianos. Carcinoma pulmón no microcítico.

\section{Introduction}

More than 1.3 million new cases of lung cancer occur worldwide every year. In the United States and in Western Europe, lung cancer is the most frequent cause of death among malignant tumors. Non-small cell lung cancer (NSCLC) represents 70 $-80 \%$ of patients with lung cancer. Treatment of these patients is a particular challenge in oncology because more than one third of patients have distant metastases at diagnosis allowing only palliative treatment ${ }^{1}$. Several meta-analyses using data from multiple randomized trials indicated that chemotherapy significantly improves survival and symptom control compared with best supportive care in stage IV NCSLC patients. Also, the 1-year survival rate was increased from $15 \%$ to $25 \%$, with an improvement in patient quality of life. However, substantial toxicity impaires the advantages in survival and symptom control of cisplatin-containing regimens $^{2,3}$. Since the 1990 s, new agents were investigated in this setting; these agents include the nucleoside analog gemcitabine (GEM), the vinca-alkaloid vinorelbine (VRL), the taxanes paclitaxel and doce- 
taxel the camptothecin-derivatives irinotecan and topotecan.

Vinorelbine is a new semi-synthetic vinca alkaloid which, as with its congeners, has a mechanismof-action of inhibiting the polymerization of microtubules in the mitosis stage of cell replication ${ }^{4,5}$. However, in pre-clinical studies, VRL appears to be more active than vinblastine and vincristine in murine tumors as well as in human tumor xenografts ${ }^{6}$. Also, its more favorable therapeutic index has been confirmed in clinical practice. Pharmaco-kinetic studies indicate avid tissue uptake (especially in lung tissue), and other pre-clinical data suggest less neuro-toxicity because it has a lesser effect on axonal micro-tubules compared to other vinca alkaloids ${ }^{7-9}$.

The activity of VRL as single agent in treatmentnaïve inoperable NSCLC has been assessed in several published studies. There have been 5 published Phase II trials comprising a total of 247 patients. The cumulative response rate was 26\% (range 12$39 \%)^{10-14}$. Also, there have been 4 large randomized studies comparing VRL with others schedules. The sample comprised a total of 503 patients treated with VRL and the overall response was 14\% (range $12-15 \%)^{15-18}$. There has been a significant benefit in survival when comparing monotherapy VRL with best-supportive-care in metastatic first-line NSCLC [19]. In a randomized phase III trial (Multicenter Italian Lung Cancer in the Elderly Study [MILES]), the combination of GEM and VRL was not more effective than single-agent GEM or VRL in elderly patients ( $\geq 70$ years) with advanced NSCLC ${ }^{20}$. In base of this trial, ASCO recommendation for elderly or performance status (PS) 2, support the use of single-agent chemotherapy ${ }^{21}$.

The initial oral formulations of VRL included a powder-filled capsule and a first-generation soft-gelatin capsule. Clinical studies of this first soft-gelatin capsule showed the feasibility of oral administration of $\mathrm{VRL}^{22}$. The activity of oral VRL in NSCLC $^{23}$ and in advanced breast cancer ${ }^{24}$ seemed to be comparable to intravenous VRL. Oral vinorelbine started in 1994 with a phase I dose-finding study in patients with advanced breast cancer ${ }^{25}$. The maximum tolerated dose was $100 \mathrm{mg} / \mathrm{m}^{2}$ weekly, and the recommended dose for further clinical investigations was $80 \mathrm{mg} / \mathrm{m}^{2}$ weekly. Dose-limiting toxicities included neutropenia, nausea/vomiting and consti- pation due to autonomic neuropathy. Based on the linearity of VRL pharmacokinetics with both routes of administration ${ }^{25}$, it was established that the oral dose of $80 \mathrm{mg} / \mathrm{m}^{2}$ corresponds to the intravenous dose of $30 \mathrm{mg} / \mathrm{m}^{2}$, and the oral dose of $60 \mathrm{mg} / \mathrm{m}^{2}$ is comparable to the intravenous dose of $25 \mathrm{mg} / \mathrm{m}^{2}$. Therefore, phase II studies of single-agent oral VRL were conducted in NSCLC and advanced breast cancer, the two major indications for the intravenous form. The initial phase II study of oral VRL [26] in chemotherapy-naïve NSCLC patients used a weekly dose of $80 \mathrm{mg} / \mathrm{m}^{2}$, the dose recommended in the phase I dose-finding study ${ }^{25}$. This trial was prematurely stopped because of excessive hematological toxicity ${ }^{26}$. In consequence, a multicenter study was initiated to investigate a new schedule of oral VRL with an intrapatient dose escalation from 60 to $80 \mathrm{mg} / \mathrm{m}^{2} /$ week.

In a recent randomized phase II trial of oral vs. intravenous VRL, the activity of oral and intravenous VRL in advanced NSCLC appears to be comparable and the safety profiles of both formulations look qualitatively similar ${ }^{27}$. We show the experience in only one centre with treatment based on oral VRL as single agent in first line advanced NSCLC in elderly patients more than 70 years.

\section{Patients and Methods}

\section{Patient eligibility}

Patients recruited into this study were required to have histologically confirmed non-small cell lung cancer. All patients were to have measurable disease target lesions on physical examination (photographs), or computed tomography (CT). Other eligibility criteria were age $\geq 70$ years, World Health Organization (WHO) performance status (PS) $\leq 2$ with a life expectancy $>3$ months, adequate bone marrow reserve (absolute granulocyte count, $>1,500 / \mu \mathrm{L}$; platelet count, $>100,000 / \mu \mathrm{L}$; hemoglobin level, $>10$ $\mathrm{g} / \mathrm{dL}$ ), as well as adequate renal and hepatic function (serum creatinine, AST, ALT and bilirubin levels $<1.25$ times the upper limit of normal). Exclusion criteria were the presence of other concomitant or metachronous cancers, brain or leptomeningeal metastases, radiation to the only measurable disease or within 4 weeks of starting chemotherapy, a pre- 
vious chemotherapy regimen, simultaneous infection disease or polyneuropathy, severe cardiac arrhythmia or heart failure, pregnancy or breast feeding.

\section{Pre-treatment evaluation}

Baseline assessments included medical history, physical examination, complete blood cell count and chemistry profiles to evaluate liver and renal function. Disease extent was quantified by CT scan of thorax and upper abdomen, and photographs of any metastatic skin lesions. All measurable disease was evaluated at least for 4 weeks before inclusion in the study. Bone scintigraphy or a brain CT scan was performed if clinically necessary and bone radiography was limited to suspected areas indicated by radio-nuclide scan. Laboratory tests: blood cell count were performed weekly before each chemotherapy cycle and biochemistry test every 3-4 weeks.

\section{Drug administration protocol}

VRL was administered on a weekly basis and continued until there was evidence of either disease progression, excessive toxicily or patient refusal. Oral VRL was supplied as $20 \mathrm{mg}$ or $30 \mathrm{mg}$ softgelatin capsules. All doses were taken with a glass of water after a meal. Primary prophylaxis with antiemetics was recommended with metoclopramide, about 30 minutes before VRL intake. In case of nausea/vomiting, we recommended more doses of metoclopramide. If despite metoclopramide, nausea/vomiting still occurred, a 5-HT3 antagonist, oral granisetron was used. Granulocyte colony-stimulating factors were allowed after the first course of treatment in patients with fever accompanying grade 3-4 neutropenia. or in case of asymptomatic grade 4 neutropenia lasting for at least five days. The use of erythropoietin was allowed in the protocol.

Complete blood cell count was checked on the day of each planned treatment. Every 3-4 weeks, a liver function test (AST and ALT) and other biochemistry test was also determined. If granulocyte count was below $1500 / \mu \mathrm{L}$, platelet count was below 75000 per $\mathrm{mm}^{3}$, or AST/ALT was over $100 \mathrm{IU} 1$ on day of each cycle, VRL administration was delayed by a week. Toxicity evaluations were based on the National Cancer Institute's Common Toxicity Crite- ria (NCI-CTC), Version 3.0. Dosing was adjusted according to the haematological tolerance of the first three administrations at $60 \mathrm{mg} / \mathrm{m}^{2} /$ week. If during this phase, no grade 4 neutropenia or no more than one episode of grade 3 neutropenia occurred, the dose was increased to $80 \mathrm{mg} / \mathrm{m}^{2}$ in subsequent administrations, otherwise therapy was continued with $60 \mathrm{mg} / \mathrm{m} 2$. In case of grade 3 asthenia or poor tolerance in the first three administrations with 60 $\mathrm{mg} / \mathrm{m}^{2}$ in this special population of elderly patients, most of then with no good performance status, we did not increased to $80 \mathrm{mg} / \mathrm{m}^{2}$. If during subsequent treatment at $80 \mathrm{mg} / \mathrm{m}^{2}$, grade 4 neutropenia or at least two consecutive episodes of grade 3 neutropenia occurred, the dose was reduced to $60 \mathrm{mg} / \mathrm{m}^{2}$ for the subsequent administrations. In case of peripheral neuropathy $\geq$ grade 3 , the administration of vinorelbine had to be held and a new examination had to be performed one week later. If the treatment could not be administered after a three-week interval because of hematological or neurologic toxicity, or other severe toxicities that made it difficult to continue the protocol treatment, we discontinued VRL.

\section{Treatment evaluation}

Patients who had received $\geq 3$ administrations were considered assessable for response and toxicities. Radiological and/or photographic evaluations were repeated every 3 cycles to evaluate response to chemotherapy. Responses to treatment were defined according to RECIST criteria ${ }^{27}$.

\section{Statistical analysis}

The primary objective of this trial was to define the activity of oral VRL in elderly patients with advanced NSCLC. Overall survival and failure free survival of this sequential schedule were performed using the Kaplan-Meier estimation method. Survival was defined as the time between initiation of treatment and death. If death had not occurred, survival time was considered censored at the last follow-up time. Failure free survival was defined as the time between initiation of treatment and failure (i.e., death or disease progression). If failure had not occurred at the time of this analysis, failure free survival was considered censored at the time of the last follow-up. 


\section{Results}

Between October 2005 and June 2006, 12 elderly patients $\geq 70$ with advanced NSCLC were included in this study. All of them were evaluable for toxicity and response. Patients' characteristics on entry into the trial are summarized in Table I. The mean age of the patients was 74 years (range: 71 to 79) with 12 $(100 \%)$ males and 0 females. Histology types were: adenocarcinoma in 5 patients (42\%), large cell carcinoma in 1 patients $(8 \%)$ and squamous cell carcinoma in 6 patients $(50 \%)$. The majority of the patients had and ECOG PS of 2, 9 patients (75\%), 3 patients with PS 1 (25\%), and no patients had PS 0. The staging was all 12 patients $(100 \%)$ with stage IV and no patients with stage IIIB.

\section{TABLE I}

Characteristics of the patients on entry into the study

\begin{tabular}{|llc|}
\hline Characteristics & & $N$ \\
\hline $\begin{array}{l}\text { Total number } \\
\text { Gender: }\end{array}$ & & 12 \\
& Male & 12 \\
Age (years): & Female & 0 \\
& Median & 74 \\
Histology: & Range & $71-79$ \\
& & \\
& Adenocarcinoma & 5 \\
& Large cell & 1 \\
& Squamous & 6 \\
& Mixed adeno-squamous & 0 \\
Performance status & & 0 \\
& 0 & 3 \\
& 1 & 9 \\
& 2 & \\
& &
\end{tabular}

\section{Efficacy and survival}

A total of 153 oral doses of VRL were administered. The median number of weekly VRL cycles was 13 (range 3-23). Five patients received six cycles or more. Nine patients had at least one administration delayed, but these delays never exceeded 8 days. Fourteen administrations were skipped because of haematological toxicity $(65 \%)$ or bad conditions $(35 \%)$. Only 1 patient received only three administrations (one cycle). Out of 11 patients receiving the second cycle, 7 patients underwent a dose escala- tion to $80 \mathrm{mg} / \mathrm{m}^{2}$. The other 4 patients remained at the $60 \mathrm{mg} / \mathrm{m} 2$ dose level: due to two episodes of grade 2 neutropenia (1 patient), and for the remaining three patients, reasons for not increasing the dose were doubt to the general conditions, and other toxicities as asthenia, gastrointestinal poor tolerance. In addition, in only 1 patient, the weekly doses had to be reduced from 80 to $60 \mathrm{mg} / \mathrm{m}^{2}$.

Response rates are shown in Table II. There were no complete responses (CR); 2 (13\%) of 12 patients achieved partial response (PR) to oral VRL. There were $6(50 \%)$ stable disease (SD), and 4 (34\%) progressive disease (PD). Respect survival, the median follow-up was 4 months (range 1-9 months). Until date, the median survival time (MST) and median progression-free survival had not been reached, and the percentage of patients lived and patients without progression until date was $66 \%$ in both respectively. Survival and progression-free survival curves are represented in Figures 1, 2.

TABLE II

Best response to therapy

\begin{tabular}{|lc|}
\hline $\begin{array}{l}\text { Overall } \\
\text { Response }\end{array}$ & N patients (\%) \\
\hline PR & $2(16)$ \\
SD & $6(50)$ \\
PD & $4(34)$ \\
\hline
\end{tabular}

\section{Toxicity}

Treatment with oral VRL in elderly patients was well tolerated, and there were no toxic deaths. Toxicity is represented in Table III. No grade 4 toxicities were observed, and grade 3 toxicities were infrequent, exclusively neutropenia in 2 patients and asthenia in other 2 patients. Rest of toxicities were grade 1 or 2 .

There were only 2 patient (17\%) who experienced grade 2 anaemia not requiring packed red cells transfusion and 4 patient (32\%) developed grade 1 anaemia. No thrombocytopenia was observed. Five patients $(41 \%)$ had grade 1 neutropenia and no patients had grade 2 neutropenia. Nonhematologic toxicity was also mild and above all asthenia, anorexia and constipation. Grade 2 Vomiting occurred in 4 patients $(33 \%)$, and grade 1 in other 4 patients 


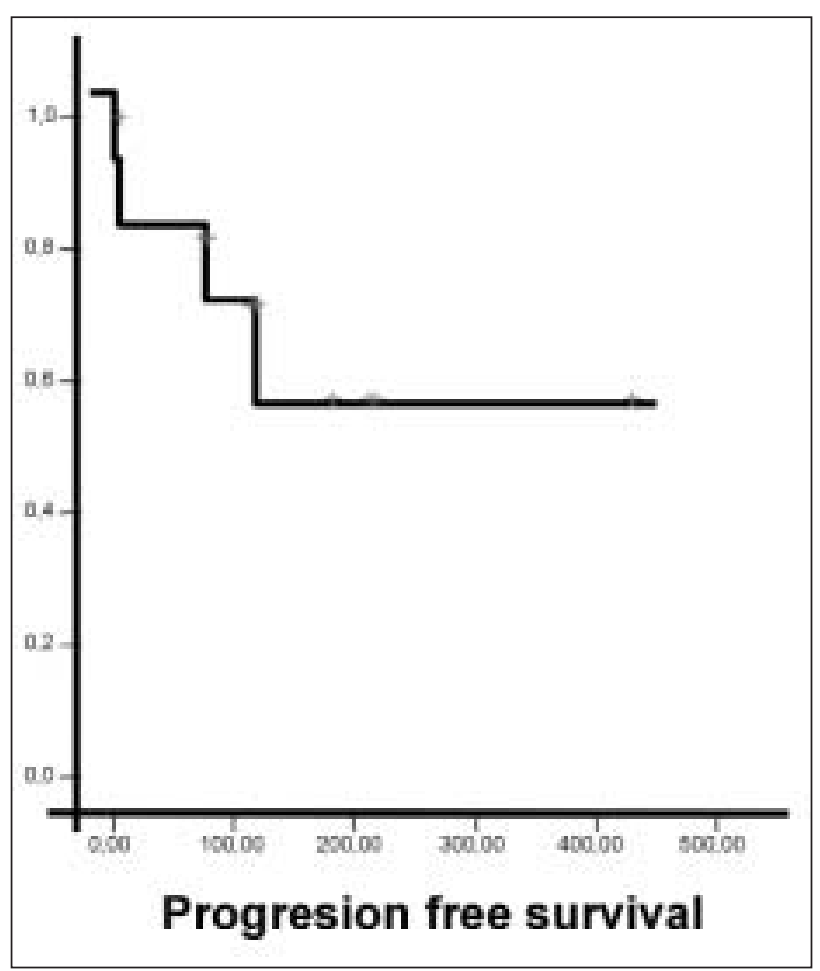

Figure 1. Curve of progression free survival,

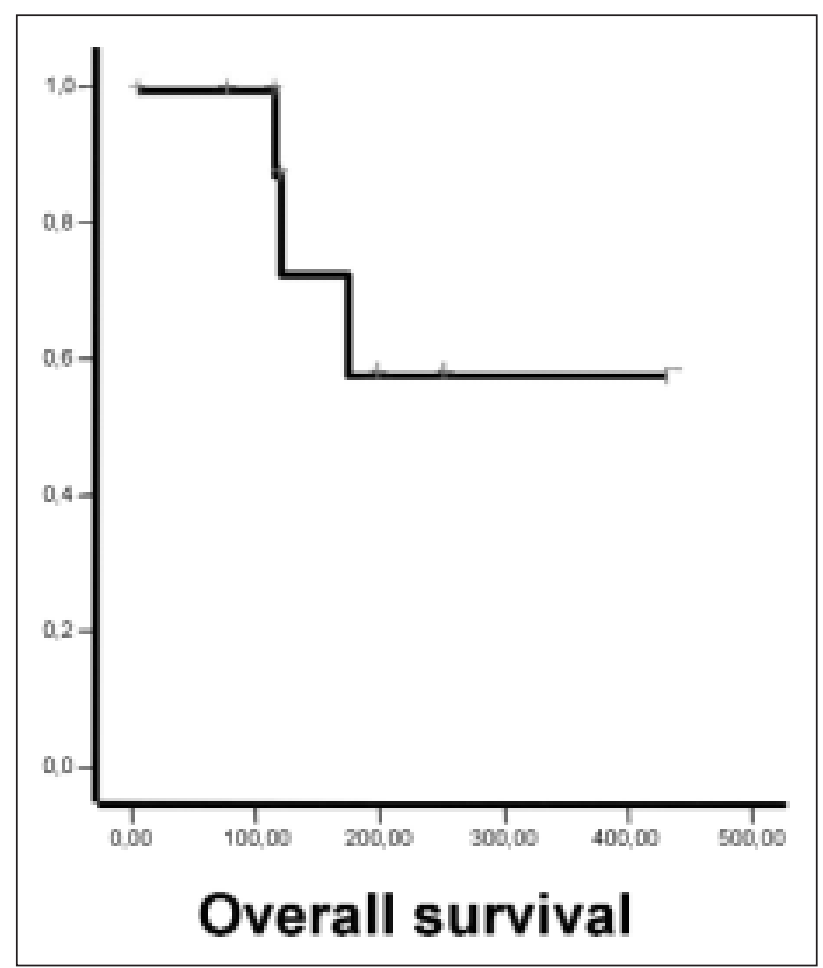

Figure 2. Curve of overall survival.

TABLE III

Grades of Toxicity

\begin{tabular}{|c|c|c|c|c|}
\hline \multirow[b]{2}{*}{ Toxicity } & \multicolumn{4}{|c|}{ Grades } \\
\hline & $G 1$ & $G 2$ & $G 3$ & G4 \\
\hline Haemoglobina & $4(32 \%)$ & $2(17 \%)$ & 0 & 0 \\
\hline Platelets & 0 & 0 & 0 & 0 \\
\hline Neutropenia & $5(41 \%)$ & 0 & $2(16 \%)$ & 0 \\
\hline Nausea/vomiting & $4(33 \%)$ & $4(33 \%)$ & 0 & 0 \\
\hline Alopecia & 0 & 0 & 0 & 0 \\
\hline Asthenia & $5(41 \%)$ & $2(16 \%)$ & $2(16 \%)$ & 0 \\
\hline Anorexia & $4(33 \%)$ & $5(41 \%)$ & 0 & 0 \\
\hline Fever & $3(25 \%)$ & $1(8 \%)$ & 0 & 0 \\
\hline Infection & 0 & $2(17 \%)$ & 0 & 0 \\
\hline Constipation & $5(41 \%)$ & $4(33 \%)$ & 0 & 0 \\
\hline Diarrhoea & $2(16 \%)$ & 0 & 0 & 0 \\
\hline Mucositis & $1(8 \%)$ & 0 & 0 & 0 \\
\hline Abdominal pain & $2(16 \%)$ & 0 & 0 & 0 \\
\hline Neurologic & $1(8 \%)$ & $3(25 \%)$ & 0 & 0 \\
\hline
\end{tabular}

(33\%). Diarrhoea was somewhat more incommon. Grade 2 asthenia was reported in 2 patients (16\%), and grade 1 in 5 patients $(41 \%)$. Anorexia grade 2 in 5 patients $(41 \%)$, and grade 1 in 4 patients $(33 \%)$. Neurosensory symptoms grade 2 were reported in 3 patients $(25 \%)$, and grade 1 in only 1 patient $(8 \%)$. Constipation grade 2 was observed in 4 patients (33\%), and grade 1 in 5 patients $(41 \%)$. There were no relevant changes in the hepatic and renal function tests (Table III). 


\section{Discussion}

Currently, standard therapy for advanced NSCLC results in overall response of $20-40 \%$, MST of 8-10 months, 1- and 2- year survival rates of 30-35 and $10-15 \%$, respectively, and only a few patients are considered long-term survivors ${ }^{1,2}$. Although the high prevalence of NSCLC in older people is clear, elderly subjects are under-represented in clinical trials. This under-representation may be a reflection of largely accepted concepts on the low benefit/risk ratio of chemotherapy in elderly patients. It is recognised that this subpopulation are less aggressively treated and more likely to be offered no systemic treatment ${ }^{29}$. Earle et $\mathrm{al}^{30}$ noted that only $22 \%$ of those aged 65 years or over received any chemotherapy. Among the 6232 elderly patients with NSCLC in the Surveillance, Epidemiology and End-Results (SEER) registry of the NCI, median survival was 30 weeks for patients treated with chemotherapy, but only 23 weeks for those receiving supportive care alone.

VRL has been evaluated in elderly patients with advanced NSCLC in a randomised trial, the ELVIS trial $^{19}$, in which intravenous VRL had a significant advantage compared with best supportive care in advanced patients $\geq 70$ years. Their median survival was 28 weeks compared with 21 weeks for patients on best supportive care $(\mathrm{P}=0.03)$. The one-year survival rate was also in favour of the VRL-treated patients: $32 \%$ versus $14 \%$, and improvement in quality of life.

Enhancing the importance of VRL in this population of patients, the MILES trial recently reported that monotherapy with either VRL or GEM is equivalent to combination therapy with both drugs [20]. This 698-patient trial examined multiple endpoints, including tumor response rate, time to progression, survival, and quality of life and observed no statistically significant differences between the single agents and the combination. The response rate in this trial with intravenous VRL was $18 \%$. This findings justified the investigation of single agent chemotherapy in older patients with metastatic NSCLC.

In a recent randomized phase II trial of oral vs. intravenous VRL designed to determine the efficacy and safety of oral VRL in previously untreated patients with advanced NSCLC, ninety-eight patients were assessable. The response rates in evaluable patients were $14 \%$ in the oral arm and $12 \%$ in the intravenous arm. The median progression-free survi- val with oral and intravenous VRL was 3.2 months and 2.1 months, respectively, and the median survival 9.3 and 7.9 months, respectively. The most common haematological toxicity was neutropenia, which was grade 3-4 in 46\% of patients and for $7 \%$ of administrations in the oral arm, and in $62 \%$ of patients and for $25 \%$ of administrations in the intravenous arm. Non-haematological toxicities including nausea, vomiting, anorexia, weight loss, diarrhoea and constipation were generally mild to moderate. So, the conclusion was that the activity of oral and intravenous VRL in advanced NSCLC appears to be comparable. The safety profiles of both formulations look qualitatively similar. Oral VRL can therefore be considered a good alternative to intravenous administration ${ }^{27}$.

Age is associated with physiologic modifications that affect drug pharmacokinetics and metabolism. Therefore, knowledge of pharmacokinetics in elderly patients is one of the major factors in deciding whether or not to reduce the dose to prevent toxicity. The study by Puozzo et $\mathrm{al}^{31}$ evaluated the influence of age on oral VRL pharmacokinetics in elderly patients with non-small-cell lung cancer (NSCLC), and compared with a reference population selected from VRL pharmacokinetic database. There was no difference between pharmacokinetic parameters, including the bioavailability factor and a similar interindividual variability between the 2 groups. Furthermore, no correlation between age and oral VRL total clearance was observed. Therefore, no requirement for oral VRL dose reduction in elderly population was suggested from a pharmacokinetic standpoint ${ }^{31}$.

Two phase II in elderly NSCLC patients treated with oral VRL as single agent in first line have been recently conducted. In the trial by Gridelly et $\mathrm{al}^{32}$, a total of 56 elderly patients $\geq 70$ were recruited starting with $60 \mathrm{mg} / \mathrm{m}^{2}$ once a week for three weeks (first cycle), followed by $80 \mathrm{mg} / \mathrm{m}^{2}$ once a week until disease progression or development of unacceptable toxicity. Treatment was well tolerated with neutropenia grade 3 or 4 in $20 \%$ and $30 \%$ respectively and febrile neutropenia in $2 \%$ of patients. Six partial responses $(11 \%)$ and 25 stable disease responses were recorded, with a disease control rate of $55 \%$. Median overall survival was 8.2 months $(95 \%$ confidence interval 6.2-11.3). The clinical benefit response rate was $31 \%$ on 32 evaluable patients. The second 
trial was carried by Kanard et $\mathrm{al}^{33}$, with 58 evaluable patients $\geq 65$ years with PS (ECOG) 0 or 1 , in $88 \%$ and PS 2 in only $12 \%$ of patients. Oral VRL 60 $\mathrm{mg} / \mathrm{m}^{2}$ per week was prescribed weekly as first-line therapy and no patients increased to $80 \mathrm{mg} / \mathrm{m}^{2}$. The response rate was of $3.4 \%$ (95\% CI: $0.4-11.9 \%$ ). Median progression-free survival was 3.5 months (95\% CI: 2.2- 5.4 months), and median overall survival was 7.5 months (95\% CI: 5-12 months).

Based on this collective background, we conducted this study of oral VRL as single agent in first line advanced NSCLC in elderly patients more than 70 years. The dose-adjustment approach was aimed to optimize the haematological tolerance of the patient, while maintaining the efficacy reported for intravenous VRL. We did not perform lung cancer symptom scale quality of life data, but in the trial by Kanard et $\mathrm{al}^{33}$, patients appeared to favor oral chemotherapy at baseline, and they continued to favor it even after 1 month. We show the results of our low size patient recruitment, with an overall response of $13 \%$ and with a median follow-up was 4 months (range, 1-9 months), the median survival time (MST) and median progression-free survival had not been reached; with $66 \%$ of patients lived until date. Of course, this data are bias for the low time of follow-up, and several patients continue with chemotherapy. The efficacy data from our trial are equivalent compared with the results in the trial by Gridelly et $\mathrm{al}^{32}$, but superior respect the data showed by Kanard et $a^{33}$. Probably this difference and the fact that there were only two episodes of severe leukopenia in that trial, suggests that a dose escalation strategy might have improved tumor response rates in the elderly trial reported here. Almost, one of the conclusions were that future studies with oral VRL in this population of patients might consider incorporating a dose escalation strategy in conjunction with careful toxicity monitoring.

In our sample, treatment with oral VRL in elderly patients was well tolerated, and there were no toxic deaths. No grade 4 toxicities were observed, and grade 3 toxicities were infrequent, exclusively neutropenia in 2 patients and asthenia in other 2 patients. Rest of toxicities were grade 1 or 2 . This findings contrast with the two reports previously commented. In the trial by Kanard et $\mathrm{al}^{33}$, in which most patients had PS $<2$, the limit of age was 65 years, and no patients increased dose to $80 \mathrm{mg} / \mathrm{m}^{2}$, howe- ver non-haematological toxicity was higher compare with our study. They had with five patients had grade 5 events, which included a fatal arrhythmia, cerebral vascular accident, a suicide, an acute exacerbation of chronic obstructive pulmonary disease with a possible infection, and an embolic event. Overall, seven patients had a grade 4 event as their most severe adverse event, and 21 patients had a grade 3 event as their most severe adverse event, although only two events of grade 4 neutropenia. In the trial by Gridelly et $\mathrm{al}^{32}$, haematological toxicity was higher with neutropenia grade 3 or 4 in $20 \%$ and $30 \%$ respectively. Again, probably this low percentage of toxicity in our trial may be partially explained by the low size of our sample.

\section{Conclusions}

Oral VRL appears to be a reasonable alternative to intravenous VRL, both in terms of activity and tolerability, in advanced, elderly NSCLC patients. Optimal schedule even in this population would be same protocol than younger patients: starting with $60 \mathrm{mg} / \mathrm{m}^{2} /$ week; If during this phase, no grade 4 neutropenia or no more than one episode of grade 3 neutropenia occurred, the dose should be increased to $80 \mathrm{mg} / \mathrm{m}^{2}$ in subsequent administrations. We will follow the inclusion of patients in this protocol.

\section{References}

1. Bunn PA Jr, Kelly K: New chemotherapeutic agents prolong survival and improve quality of life in non-small cell lung cancer: A review of the literature and future directions. Clin Cancer Res 1998;5:1087-1100.

2. Grilli R, Oxman AD, Julian JM. Chemotherapy is for advanced non-small cell lung cancer. How much benefit is enough? J Clin Oncol 1993;11:1866-72.

3. Non Small Cell Lung Cancer Collaborative Group. Chemotherapy in non-small cell lung cancer: a meta-analysis using updated data on individual patients from 52 randomized clinical trials. Br Med J 1955;311:899-909.

4. Rahmani R, Martin M, Barbet J, et al. Radioimmunoassay and preliminary pharmacokinetic studies in rats of 5 -Noranhydrovinblastine (Navelbine). Cancer Res 1984;44:5609-13.

5. Paintrand MR, Pignot I. Navelbine: An ultrastructure study of its effects. J Electron Microscopy 1983;32:115-24.

6. Cros S, Wright M, Morimoto M, et al. Experimental anti- 
tumour activity of Navelbine. Semin Oncol 1989:16(suppl 4):15-20

7. Chiappori A, Russell F, Devore M, et al. New agents in the management of non-small cell lung cancer. Cancer Control Journal of the Moffit Cancer Center.1997; Vol. 4, n ${ }^{\circ} 4$ : 317-25.

8. Schilling T, Fiebig H, Karpel Fronious S, et al. Clinical phase I and pharmacokinetic trial of Navelbine administered as single intravenous as single intravenous bolus every 21 days in cancer patients. Invest N Drugs 1996;14:371-8.

9. Mathe G, Reizenstein P. Phase I pharmacologic study of a new vinca-alkaloid: Navelbine. Cancer Lett 1985;27:285-93.

10. Depierre A, Lemarie E, Dabouis G, et al. A phase II study of Navelbine (Vinorelbine) in the treatment of non-small cell lung cancer. Am J Clin Oncol 1991;14:115-9.

11. Furuse K, Kubota K, Kawahara M, et al. A phase II study of vinorelbine, a new derivative of vinca alkaloid, for previously untreated advanced non-small-cell lung cancer. Lung Cancer 1994;11:385-91.

12. Veronesi A, Crivellari D, Magri MD, et al. Vinorelbine treatment of advanced non-small cell lung cancer with special emphasis on elderly patients. Eur J Cancer 1996;32A:1809-11.

13. Gridelli C, Perrone F, Gallo C, et al. Vinorelbine is well tolerated and active in the treatment of elderly patients with advanced non-small-cell lung cancer. A two-stage phase II study. Eur J Cancer 1997;33:392-7.

14. Tononi A, Panzini I, Olivero G, et al. Vinorelbine chemotherapy in non-small cell lung cancer. Experience in elderly patients. J Chemother 1997;9:304-8.

15. Crawford J, O`Rourke M, Schiller H, et al. Randomized trial with Vinorelbine compared with Fluoracil plus Leucovorin in patients with stage IV NSCLC. J Clin Oncol 1996;14:2774-8.

16. Depierre A, Chastang C, Choix E, et al. Vinorelbine versus vinorelbine plus cisplatin in advanced non-small-cell lung cancer: A randomized trial. Ann Oncol 1994;5:37-42.

17. Le Chevalier T, Brisgand D, Douillard JY, et al. Randomized study of vinorelbine and cisplatin versus vindesina and cisplatin verus vinorelbine alone in advanced non-smallcell lung cancer: Results of an European multicenter trial including 612 patients. J Clin Oncol 1994;12:360-7.

18. Frasci G, Lorusso V, Panza N. Gemcitabine plus vinorelbine versus vinorelbine alone in elderly patients with advanced non-small-cell lung cancer. J Clin Oncol 2000;18(13):2529-36.

19. Italian Collaborative Group. Effects of vinorelbine on quality of life and survival of elderly patients with advanced non-small-cell lung cancer. The Elderly Lung Cancer Vinorelbine Italian Study Group. J Natl Cancer Inst. 1999 Jan 6;91(1):66-72.

20. Gridelli C, Perrone F, Gallo C, et al: Chemotherapy for elderly patients with advanced non-small lung cancer: The Multicenter Italian Lung Cancer in the Elderly Study (MILES) phase III randomized trial. J Natl Cancer Inst 2003; 95:362-372.
21. Pfister DG, Johnson DH, Azzoli CG, et al. American Society of Clinical Oncology treatment of unresectable nonsmall-cell lung cancer guideline: update 2003. J Clin Oncol 2003;22(2):330-53.

22. Rowinsky EK. Noe DA. Lucas VS ct al. A phase I pharmacokinetic and absolute bioavailability study of oral vinorelbine (Navelbine) in solid tumor patients J Clin Oncol 1994; 12: 1754-63.

23. Vokes EE, Rosenberg RK. Jahanzeb M et al. Multicenter phase II study of weekly oral vinorelbine for stage IV nonsmall-cell King cancer J Clin Oncol 1995: 13: 637-44.

24. Winer E. Duke U, Durham NC et al. An US multicenier phase II trial of oral Navelbine11" in elderly women with advanced breast cancer. Breast Cancer Res Treat 1993; 27: 136.

25. Chevallier B. Bonneterre J. Lebras F el al. Phase I trial of oral vinorelbine in patients with advanced breast cancer. Br J Cancer 1997: 75: 45 (Abstr 107).

26. Depierre A, Jassem J. Ramlau R et al. Feasibility and safety of Navelbine oral (NVBpo) with an intrapatient dose escalation vs Navelbine intravenous (NVB i v.) in advanced/metastatic non-small-cell lung cancer. Lung Cancer 2000; 29 (Suppl 1): 35 (Abstr 112).

27. Jassem J, Ramlau R, Karnicka-Mfodkowska H, et al. A multicenter randomized phase II study of oral vs. intravenous vinorelbine in advanced non-small-cell lung cancer patients. Ann Oncol 2001;12: 1375-81.

28. Gehan EA, Tefft MC. Will there be resistance to the RECIST (Response Evaluation Criteria in Solid Tumors)?. J Natl Cancer Inst. 2000; 92(3):179-81.

29. Weinmann M, Jeremic B, Toomes H, Friedel G, Bamberg M. Treatment of lung cancer in the elderly Part I: nonsmall cell lung cancer. Lung Cancer 2003; 39: 223-53.

30. Earle CC, Venditi LN, Neumann PJ, et al. Who gets chemotherapy for metastatic lung cancer. Chest 2000;117: 1239-46.

31. Puozzo C, Gridelli C. Non-small-cell lung cancer in elderly patients: influence of age on vinorelbine oral pharmacokinetics. Clin Lung Cancer. 2004 Jan;5(4):237-42.

32. Gridelli C, Manegold C, Mali P. Oral vinorelbine given as monotherapy to advanced, elderly NSCLC patients: a multicentre phase II trial. Eur J Cancer 2004;40:2424-31.

33. Kanard A, Jatoi A, Castillo R. Oral vinorelbine for the treatment of metastatic non-small cell lung cancer in elderly patients: a phase II trial of efficacy and toxicity. Lung Cancer 2004; 43:45-53. 